\title{
A Review of Direct Investment between China and ASEAN countries
}

\author{
Yue Yang* \\ Business school, Yunnan university of finance and \\ economics \\ Kunming, China \\ 616778144@qq.com
}

\author{
Qiang Zhang \\ Business school ,Yunnan university of finance and \\ economics \\ Kunming, China \\ 625341950@qq.com
}

\begin{abstract}
The establishment of the China-ASEAN Free Trade Area has brought unprecedented opportunities and space as well as greater common interests for China and ASEAN in the developing countries and regions. The desire to seek common development based on economic cooperation has become increasingly strong. In the meantime, this paper reviews the domestic and foreign literature on the issue of bilateral direct investment disputes between China and ASEAN, divided into two categories of views: positive role and negative effects, which is helpful to explore and prove the direct investment between China and ASEAN countries in the future.
\end{abstract}

Keywords-China - ASEAN free trade area; foreign direct investment; investment country and host country

\section{INTRODUCTION}

Since the end of the Cold War in 1990s, peace and development have become the theme of the times. All countries take economic development as their primary task and adjust their foreign policies accordingly. East Asia is the place where the interests of the foreign powers are concentrated, and its own regional economic integration process is influenced by the extraterritorial factors. The recession in the United States is that East Asian countries have a greater initiative in their own regional affairs. Following the example of the US policy, Japan, a regional power that is the leading economic aid donor to ASEAN and the largest overseas investor, began to return to Asia after a long economic downturn, hoping to expand trade and investment opportunities through free trade agreements with Asian countries. However, its attitude to history and the idea of "East Asia centered economic cooperation" is that there is still a big gap in the true integration of East Asia. These will certainly bring unprecedented opportunities and space to the construction of the China-ASEAN Free Trade area, and at the same time bring greater common benefits to China and ASEAN in the developing countries and regions. The desire to seek common development based on economic cooperation is becoming stronger and stronger. In accordance with the building of the partnership of good-neighborliness and mutual trust, the two sides have further formed a relatively perfect and well-functioning framework for comprehensive dialogue and cooperation, as well as corresponding rules, so the concept of joint cooperation has become more and more solid. In terms of regional economic integration, although ASEAN has taken the lead in other countries in East Asia, however, because of its

*Corresponding author own restrictions on its size and the impact of the Southeast Asian financial crisis, economic development has encountered certain obstacles. We should further seek new impetus for sustainable development; However, because China lacks the experience of the mechanism of regional economic cooperation for a long time, the rapid growth of its own economy must also be related to the regional economic integration. In November 2002, China and ASEAN finally emerged from the East Asian regional economic cooperation. Became the most influential step in history "Framework agreement on comprehensive economic cooperation between China and ASEAN" Sign it. Here, "China ASEAN Framework Agreement on Economic Cooperation" The basic framework of the China-ASEAN Free Trade area has been basically determined. The agreement stipulates that by 2010, China and six ASEAN member countries, including Brunei, Malaysia and Indonesia, will substantially eliminate tariffs on most products. Four new ASEAN members, Cambodia, Laos, Myanmar and Vietnam, will enjoy an additional five years of transition. In January 1st 2010, the China-ASEAN Free Trade area, which was officially launched in January 1st 2010, has become the third largest free trade area in the world. The European Union and the North American Free Trade area are respectively in the first two places.

From the perspective of the state, the China-ASEAN Free Trade Area was proposed on the basis of common economic interests .The formation of a free trade zone between China and ASEAN not only increased the competitiveness among enterprises, thus effectively complementing each other's advantages. Facilitating investment and economic and technical cooperation in the region by effectively integrating geographical facilitation, facilitating the flow of people, commodities and information among the different countries of the region, and possibly more effectively promoting the development of regional markets, In order to be able to create more wealth, thus greatly increasing the well-being of the peoples of the region.

\section{DOMESTIC AND FOREIGN LITERATURE REVIEW}

\section{A. Foreign Direct Investment}

The first study in the theory of foreign direct investment (FDI) is due to the study of foreign investment in developed 
countries. In 1957, Mundell states in International Trade and Factor Mobility that there is an alternative relationship between investment and trade. In his view, the existence of trade barriers will generate capital flows, and the barriers of capital flow will generate trade [1].A professor at Harvard University in the United States named Vernon (1966) put forward the theory of product life cycle (PLC) in "International Investment and International Trade in the Product Cycle". In his view, the technological development of new products generally goes through three stages: Innovation, maturity and standardization; the proportion of factors of production of this kind of products will also change regularly, beginning to change from technology-intensive to labor-intensive, and then from capitalintensive to labor-intensive. In addition, those countries with relatively large production advantages will also change accordingly, starting from individual developed countries to general developed countries, and then to developing countries. The trade strategies of the innovative countries also begin to change slowly, that is, to produce and export to the neighboring countries, in order to reduce production and exports. And then invest in close countries, and then stop production. According to the investment, production part is transferred to developing countries. Their own needs are gradually satisfied through overseas imports [2].

American Scholar Hymer first analyze the foreign investment in the United States from 1914 to 1956, and put forward monopoly advantage to explain the occurrence of FDI. in his PHD dissertation "The International Operations of National Firms: A Study of Direct Foreign Investment". After its development by Kindleberger, Caves, Buckley and Casson [4][5][6] ,Professor J. H. Dunning of the University of Reading, UK, absorbs the essence of the various OFDI theories that have emerged over the past 20 years, in passage named "Trade, location and economic activity and the multinational enterprise: A search for an eclectic approach", elaborating the theory of international production compromise in detail, putting forward the necessary advantages of foreign direct investment., there are three kinds: firstly, "Ownership" refers to the ownership of a country's business, while foreign enterprises are impossible to get assets and ownership.; secondly, "Internalization" means that those enterprises whose ownership is dominant can expand their business activities, using these advantages internally and getting the maximum profit.; thirdly, "Location" refers to the favorable conditions for the host country to provide foreign enterprises with direct investment in the country. He believes that only when enterprises have the above three advantages at the same time can they have the conditions for foreign direct investment [7]. Since 1990s. Veugelers use the game theory analysis tool, explaining the phenomenon of strategic foreign investment in the field of international investment in published article "Strategic Intentives for Multinational Operations". He states that as a result of the change of international operating environment, transnational companies make strategic changes, trend of strategic foreign investment of transnational companies is becoming more and more obvious. This theory complements the monopoly advantage theory which presents that enterprises are considered from their own specific advantages, less considering the market competition and competitors, lacking analysis of the interact influence between transnational corporations [8].
In 1977, Lecraw investigates more than 20 foreign direct investment companies from different Asian countries in Thailand in his paper "Direct Investment by Firms from Less Developed Countries". And it is concluded that these companies are located in labor-intensive industries, and the market is not only for the host country but also for overseas; this type of investment is adapted to the application of labourintensive technologies, small-scale mature production, generic products; investors prefer to hold minority shares in joint ventures with local enterprises, and the family relationship of the host company plays an important role in the business. Compared with foreign direct investment from developed countries, this kind of FDI has higher degree of autonomy [9].Afterwards, Wells (1983) states that the biggest shortcomings of the traditional theory of foreign direct investment is the put competitive advantage of transnational companies in absolutization in his paper "Third World Multinationals: The Rise of Foreign Investment from Developing Countries". He thinks that the competitive advantages of transnational companies in developing countries are relative, most of them are low in production cost, and this low production cost is closely related to the market characteristics of their home country. Wells also points out in the paper that not only because of its large-scale production of modern technology in a strong competitive advantage, but also those technology suitable for small-scale production can have big advantage in the competition. In summary, the comparative advantages of transnational companies in developing countries usually have the following three aspects:(1) Small-scale production technology as a result of its greater flexibility in production; (2) having a certain advantage in the overseas production of national products, most of the overseas investment enterprises in developing countries need to set up a group to serve the same ethnic groups overseas; (3) low price marketing strategy of products is an important weapon for transnational companies in developing countries to seize the market. The product marketing strategy of developed country transnational companies is usually a large amount of advertising costs to create famous brand effects. Developing countries, on the other hand, spend less on advertising and use low-cost marketing strategies [10]. Lallen and Tolentinoy further supplement the Wells theory, emphasizing the regeneration process of technology introduction. That is, the transnational companies of developing countries do not simply copy the imported foreign technology, but do further digestion, absorption, improvement and innovation of the technology. It is precisely because of this kind of innovation activity, bringing new vitality to the imported technology, and then bringing new competitive advantage to those enterprises that introduce technology. As it is accumulated step by step, technical ability is developed, further promoting upgrading of the industrial structure of outward direct investment in developing countries [11] [12].

In 1988, Dunning came to a similar conclusion based on different theoretical frameworks. In his theory of investment development path (IDP), he regards the development of a country's FDI as a process corresponding to the development of the country's economy. With the economic development to a certain level, FDIs will be exported gradually, a country must first accept a certain amount of FDI inflow [13]. 
In 2006 ASEAN-UNCTAD seminar, Daisuke Hiratsuka presents that the reason for FDI among ASEAN regions is transport costs in his FDI theme paper "Outward FDI from and Intraregional FDI in ASEAN: Trends and Drivers": if the cost of transporting the goods is too high, the enterprise will place the production department near the market. He believes that there are four forces driving ASEAN multinational enterprises to invest abroad: first, the efficiency of foreign direct investment, the pursuit of the host country cheap wage rate; second, market-oriented type, in order to enter the host country's huge market; third, "supplier follows the production line" type of foreign direct investment, pointing that the host country suppliers follow the foreign manufacturing production line for direct investment; fourth, function-oriented foreign direct investment [14].The research subjects of this study are ASEAN, especially the more developed countries such as Singapore, Malaysia, Thailand, and even Hong Kong, Japan, Korea and so on. The study on the underdeveloped countries in ASEAN member countries is difficult to consult, not even to mention the motivation and cause analysis of FDI from China and Yunnan Province to ASEAN. After analyzing ten country, AtherMaqsood Ahmed [15 ] has concluded that FDI has played an active role in promoting national economic growth. After analyzing the 30-year sample data of 91 developing countries in the world, Ali AI-sadig [16] is found that the entry of FDI will increase investment in the enterprise sector that affects the host country, and then affect the economic growth of the host country.

\section{B. Direct Investment Between China and ASEAN Countries Plays a Positive Role}

Some scholars believe that China's foreign investment is a double-edged sword, which not only brings some positive effects to the host country, but also brings some negative effects. At present, there are some researches on FDI from China to the ASEAN Free Trade area, which are limited to the fragments of some literature, and lack of systematic research framework and in-depth empirical theoretical analysis. Therefore, ASEAN countries have a great advantage in attracting Chinese foreign investment and have become a small free trade economic zone.

At present, ASEAN's economic integration gives a big boost to China's investment in the region. Many scholars believe that the establishment of China-ASEAN Free Trade area (CAFTA) has great advantages in attracting China's FDI. According to Gao Ting: in vertical FDI, the closer the distance between home country and host country is, the lower the cost of transportation and information acquisition capacity of home country is. Therefore, those countries with low income have a small market. However, most of the FDI flows to low-income countries are vertical. as a result, the countries in the subregion have obvious advantages in attracting Chinese capital exports [17]. The effective combination of ASEAN regional economic integration and regional economy is the result of China's investment in ASEAN countries. Chinese scholars Du Qunyang and Song Yuhuazhang [18] construct an analytical framework for the FDI effect of China-ASEAN Free Trade Area (CAFTA). This effect is bound to lead to an increase in China's investment in ASEAN countries.
In some literature, scholars in domestic and abroad have some controversy on the impact of China's direct investment in ASEAN, these theoretical results for the study of this paper also have reference significance. First of all, some scholars believe that China's investment in ASEAN countries, whether home country or host country, has a positive impact. Wang Zhongbao [19] refers that the benefit of international investment is the increase of welfare brought by the global allocation of capital, and uses the two-gap model to explain the investment interests of developing countries. Most countries in China and ASEAN Free Trade Area belong to developing countries. These two models can also be used to illustrate the positive impact of China's investment in ASEAN countries.

Indeed, many studies on the impact of FDI on capitalimporting countries have tended to the positive effects of FDI. Based on time series, in 2004, empirical study of Kanta Marwah, Akbar Tavakoli shows that the FDI attracted by Indonesia, Malaysia, the Philippines and Thailand has positive impact on their economic growth and productivity [20]. This result is consistent with the results of Jeffrey sachs (2000)'s annual study, that is, importing and allowing the free flow of FDI are two channels for absorbing high technology from abroad [21]. Based on data from 84 countries during 19701999, domestic scholars named Li Xiaoying and Liu Xia-ming [22] studys whether FDI affects economic growth. The results shows that there is a strong correlation between two parts, which is consistent with some foreign scholars' study of Thailand.

\section{Direct Investment between China and ASEAN Countries has a Negative Effect}

Gong Zhankui [23], a domestic scholar, believes that compared with ASEAN, the entry of foreign capital has a positive effect, which can also bring about negative effects such as crowding out the host country's market, restraining the development of the host country's childish industries, and so on. Chia Siow Yue, a foreign scholar, also elaborate about this problem, thinking that the traditional FDI is generally focused on the exploitation of natural resources and import substitutes. As a result, a series of problems arise, for the protection of foreign investment industries, usually takes the expense of domestic producers, thereby protecting foreign producers [24].

In 2008, the Chinese domestic scholar Yan Fangzhang also made a lot of research on "the strategy of GMS attracting FDI based on the sustainable development of regional economy". The scale of foreign capital of GMS countries in the ASEAN Free Trade area has been rising continuously, however, because of the inconsistency of investment and environmental policies among the member countries, the imbalance of the distribution of domestic funds is caused. These is also negative impact on the sustainable development environment [25]. Fang Wenchao and Xiao Chenming [26] (They have made an empirical analysis of Structural similarity of export commodities and Bilateral trade cooperation in China and the Four ASEAN countries (Indonesia, Malaysia, Thailand and Philippines).It is found that the structural similarity of export commodity between China and ASEAN "four tigers" is on the whole rising, and there is trade competition. 
There has been a lot of controversy over whether FDI has an impact on economic growth in practice. Although many studies prove that FDI has a positive impact on economic growth, some scholars believe that there is a negative correlation between these two variables. The increase in the controversy may be due to insufficient data collection. Borensztein argues that differences in the absorptive capacity of technology can explain the impact of FDI on the economic growth of countries. For established FDI, high human capital input from the host country can produce a high rate of output growth [27].

According to Bengoa and Sanchez-Roblesn (2003), through a large number of studies, showing that the inflow of FDI is positively related to economic growth. This premise, however, requires the host country to have a mix of human capital, economic stability and a free market. Some empirical results show that the positive effects of FDI are not always positively related to the absorptive capacity of technology. For example, the study of Bende-Nabende (2003) shows that the long-term direct impact of FDI on output is greater in the Philippines and Thailand than in Japan and Taiwan. Obviously, the ability of absorbing technology of Philippines and Thailand are not as strong as Taiwan, as the influence of FDI on the host country's economy depends on the country's economic, technological conditions and the basis of cooperation [28] [29] [30].

A rchanun Kohpaiboon agrees with this view, that is, the positive impact of FDI on economic growth is not automatic, it depends on the measures taken by different countries. He takes Thailand as an example to illustrate the link between foreign trade policy and FDI promoting economic growth, that is, the impact of FDI on countries that adopted by the form of EP (Export-Prompt) foreign trade organization is more than that of IP (Import-Prompt) [31]. Professor She Minhua [32], a domestic scholar, sums up this influence as follows: whether absorbing FDI to solve the problem of technological gap and lag in the process of economic growth can achieve this goal mainly depends on: first, whether the host country has trained human resources; second, whether the entrepreneurs in the host country can effectively use the acquired technology and gradually transform and innovate.

Third, some foreign scholars who hold the view of "China threat" think that the rapid economic growth of China poses a threat on neighboring countries. China's outward investment can help host countries to understand and master advanced production technology and management skills, but it would be very difficult and costly for these countries to achieve this goal. Furthermore, when the scale of external debt is too large and beyond the capacity of the national economy, debt inflation will also induce hyperinflation, and eventually lead to economic crisis. On this issue, Sun Zhaodong, Zhang Zhiqian and others [33] also hold the same view when they analyze the causes of Vietnam's economic crisis, namely, the huge influx of foreign capital can push up Vietnam's asset prices and form a bubble. With the bursting of the bubble, foreign profits flee, making a fatal blow to Vietnam which has weak economic base Some foreign scholars accuse China of participating in the regional cooperation of ASEAN countries, increasing investment in mining, energy, tourism, agricultural development and other industries, resulting in a large influx of pollution-intensive industrial projects. In particular, the development of the Great Mekong River causes environmental and ecological damage to other GMS countries. Environmental issues are indeed very important in sub-regional cooperation, as mentioned by domestic scholars Wang Gucheng and Li Peng (2009). Ecological environment and quality of life is an important factor that affects the function evolution of economic corridor. Therefore, cooperation in the framework of ASEAN should not only attach importance to economic operation, while neglecting the decisive role of natural ecosystems in the economy. It should follow Rawls' principle of "equal freedom" and the principle of "maximization of the interests of unprivileged classed" and avoid Harding's "The Tragedy of the Commons " [34] [35].

\section{An Empirical Study of FDI}

In a large number of studies of direct investment flows, foreign scholars have used the gravity model to carry out a large number of analysis, Tinbergen [36] and Tinbergen [37] use gravitational models to find that the size of bilateral trade flows between the two countries is positively proportional to their economic aggregates and the distance between them is inversely proportional. The economic aggregate of the exporting country reflects the potential supply capacity to some extent, while the economic aggregate of the importing country also reflects the potential demand capacity to some extent. The distance between the two sides, that is, the cost of transportation, constitutes a factor of resistance in trade between the two countries.

The first people to use gravity models to explain the problem of investment flows is economist named Anderson [38]; Matyas [39] puts forward a "three-level index model" of export, import and time cross-sectional data. The positive correlation between GDP and investment flow is found by using panel data analysis method. Fidrmuc [41] does a large number of empirical studies on the trade and investment flows of the eastern and central European countries which based on the total GDP data of the two countries and the spatial distance between the capitals. It is found that there is a positive correlation between the data and the total GDP volume and negative correlation in distance. Peter Egger and Michale Pfaffermayr [41] analyze FDI and economic integration of EU in 1990s by using gravity model and conclusions are ideal. Due to the gradual application of panel data analysis, the problems of country and time specific effects that have been neglected is solved to some extent. For the actual situation of China, Gu Kejian [42] put forward his own views, he thinks: it is necessary to add an extroverted trade transfer driving variable to the construction of China's trade gravity model. In constructing China's trade gravity model, the influence of transition economy on China's trade flow and direction of flow must be considered .

Therefore, domestic and foreign scholars think that it is necessary and feasible to do further empirical research on bilateral trade and investment flows between countries in very close geographical distance by using this model. 


\section{CONCLUSION}

It can be seen from the above relevant literature that there are not many studies on the impact of the Free Trade Area on direct investment after the commencement of Free Trade Area.

First, the number of domestic and foreign literature focusing on the use of foreign investment and foreign investment in China and the literature on the investment between China and ASEAN Free Trade area is small. In addition, the construction of China-ASEAN Free Trade Area at home country and abroad is mainly qualitative analysis, quantitative analysis of most of the literature only stays in the overall level of data, not digging deeply into the industry data. Thirdly, in the quantitative analysis of the overall effect of direct investment in China-ASEAN Free Trade Area, there are not many literatures on the use of gravity model for empirical research, mainly on problems of location choice. Finally, it is especially important to be noted that the above documents only analyze the situation of foreign direct investment in China. As Yunnan Province is located in the western part of our country, the quantity of foreign direct absorption is small and the quality is not in high level, few scholars carry on the special research. There are still some gaps in the literature concerning investment between Yunnan and ASEAN, that is, the research on the inter-provincial participation in regional direct investment cooperation. Future research can be done in this area.

\section{ACKNOWLEDGMENT}

Thanks to Professor Wen Shuhui and Professor Zhu Li for her guidance and valuable advice.

\section{REFERENCES}

[1] R. A. Mundell, International Trade and Factor Mobility, American Economic Review, 1957, (6):321-335.

[2] R. Vernon, International Investment and International Trade in the Product Cycle, Quarterly Journal of Economics. 1996, 80(3)

[3] S. H. Hymer. The International Operations of National Firms: A Study of Direct Foreign Investment. PHD Dissertation, MIT. (published by MIT Press, 1976)

[4] C. P. Kindleberger, Monopolistic Theory of Direct Foreign Investment, Transnational Corporation and World Orders: Readings in International Political Economy, 1975

[5] Caves, Richard E Multinational Enterprises and Economics Anlysis. Second Edition. Cambridge: Cambridge University Press., 1971.

[6] Buckley and M. Casson, Multinational Enterprises in the World Economy: Essays in Honor of Jonhn Dunning. Aldershot: Edward Elgar. 1976

[7] J. H. Dunning, Trade, location and economic activity and the multinational enterprise: A search for an eclectic approach. In: B.Ohlin, P. Hesselborn and P. Wijkman, Editors, The international allocation of economics activity, MacMillan, London.

[8] Veugelers, Strategic Intentives for Multinational Operations.Managerial and Decision Economics, Vol.16,1995.

[9] D. J. Lecraw, Direct Investment by Firms from Less Developed Countries, Oxford Economic Papers, 29(3): 442-457

[10] L. Wells, Jr. Third World Multinationals: The Rise of Foreign Investment from Developing Countires. Cambridge: MIT Press. 1983

[11] S. Lall, The New Multinationals: The Spread of Third World Enterprises. Brisbane: Johm Wiley \& Sons. 1983
[12] P. E. Tolentino, Technological Innovation and Third World Multinationals. London: Routledge. 1993

[13] Dunning, H. John. Explaining International Production. London: Unwin Hyman. 1988

[14] Daisuke Hiratsuka. Outward FDI from and Intraregional FDI in ASEAN Trends and Drivers, ASEAN-UNCTAD Annual Seminar. 2006

[15] MuhammadAzam, AtherMaqsood Ahmed .Role of human capital and foreign direct investment in promoting economic growth : Evidence from Commonwealth of Independent States [J].International Journal of Social Economics,2015(42):98- 111.

[16] Ali Al- Sadig. The effects of foreign direct investment on private domestic investment: evidence from developing countries [J].Empirical Economics, 2013(44):1267- 1275.

[17] Gao Ting. Foreign Direct Investment from Developing Asia: Some Distinctive Features. Economics Letters, Volume 86, Issue 1, January 2005, Pages 29-35.

[18] Du Qunyang, Song Yuhua; China - ASEAN Free Trade Area FDI effect [J]. international trade issues, 2004(3).

[19] Wang Zhongbao. Changes in relationship between economic globalization and the interests of China [M]. Shanghai: Fudan University Press, 2007.

[20] Kanta Marwah, Akbar Tavakoli . The Effect of Foreign Capital and Imports on Economic Growth: Further Evidence from Four Asian Countries (1970-1998).Journal of Asian Economics, 15 (2004) 399-413

[21] Sachs, J. D. (2000). Globalization and Patterns of Economic Development. Weltwirtschaftliches, Archiv, 136(4),579-600.

[22] Xiaoying Li, Xiaming Liu. Foreign Direct Investment and Economic Growth: An Increasingly Endogenous Relationship. World Development Volume 33, Issue 3, March 2005, Pages 393-407.

[23] Gong Zhankui, Meng Xia, Liu Chenyang. China and ASEAN economic integration: Model comparison and policy choice [M]. Beijing: China University of Foreign Economics and Trade Press, 2003.

[24] Chia Siow Yue. ASEAN Strategies on Foreign Direct Investment and Prospects for ASEAN-India Investments. Journal of Asian Economics, Volume 7, Issue 4, Winter 1996, Pages 701-721.

[25] Yan Fang; GMS attracting FDI strategy based on the sustainable development of regional economy [J]. Journal of Guangxi University: Philosophy and Society Edition, 2008(05).

[26] Fang Wenchao and Xiao Chenming. The error of "the fallacy of Synthesis": an empirical Analysis of the first Anniversary of ChinaASEAN Free Trade area[J]International trade issues(01)88-98.

[27] E. Borensztein, J. Gregorio, \& J. Lee, How Does Foreign Direct Investment Affect Economic Growth. Journal of International Economics, 45(1), 115-135.1998.

[28] M. Bengoa, \& B. Sanchez-Robles, Foreign Direct Investment, Economic Freedom and Growth: New Evidence from Latin America. European Journal of Political Economy, 19(3), 529-545.2003.

[29] A. Bende-Nabende, J. Ford, B. Santoso, \& S. Sen, The Interaction between FDI, Output and the Spillover Variables: Co-integration and VAR Analyses for APEC, 1965-99. Applied Economics Letters, 10 (3), 165-172.2003.

[30] F. Sjoholm, Technology Gaps, Competition and Spillovers from Direct Investment: Evidence from Establishment Data. Journal of Development Studies, 36(1), 53-73.1999.

[31] Archanun Kohpaiboon: Foreign Trade Regimes and the FDI-Growth Nexus: Case Study of Thailand. the Journal of Development Studies,Vol.40,No.2,December 2003, 2003, pp.55-69.

[32] She Minhua; The impact of foreign direct investment on the developing countries of the Middle East and its debate [J]. Financial science, 2003(S1).

[33] Sun Zhaodong. Vietnam "crisis" [M]. Beijing: China Economic Press 2008.

[34] Wang Gucheng and Li Peng; Research on the evolution mechanism of the function of the regional economic corridor in the next GMS framework $[\mathrm{J}]$. Journal of Zhengzhou Institute of Aeronautics Industry Management, 2009(04).

[35] Arthur. O'Sullivan, Urban economics, Peking University Press, 2008. 
[36] J. Tingergen, Shaping the World Economy , Appendix V I,"A n Analysis of World Trade Flows"[M]. New York: Twentieth Century Fund, 1962.

[37] P. Poyhonen, "A Tentative Model of the Volume of Trade Between Countries[J]. "Weltw irtschaf tliches A rchiv , 90 (1) , 1963.

[38] J. E. Anderson. A Theoretical Foundation for the Gravity Eguation[J]. American Economic Review,1979.69(1):106-116.

[39] L. Matyas, "P roper Econometric Specification of the Gravity Model. " The World Economy , 20 (3), 1997.
[40] Fidrmuc, Jan and J. Fidrmuc, "Disintegration and Trade. "CEPS Discussion Paper 2641, 2000.

[41] P. Egger,"A Note on the Proper Econometric Specification of the Gravity Equation. 'Econom ics Letters, 2000.

[42] Valley Kejian, International economics' development and application for gravity model [J]. World economy, 2001 (2), pp:14-24. 